\title{
Leptatherum (Poaceae): A New Genus Record for the Flora of Turkey
}

\author{
Salih TERZIOĞLU ${ }^{1 *} \odot$, Kezban ÖZKAN ${ }^{1} \odot$ \\ ${ }^{1}$ Karadeniz Technical University, Faculty of Forestry, Trabzon, TURKEY \\ ${ }^{*}$ Corresponding Author: sterzi@ktu.edu.tr
}

Received Date: 08.01.2020

Accepted Date: 28.07 .2020

Abstract

Aim of study: This study aimed to contribute the vascular plant species diversity of Turkey.

Area of study: A8 Trabzon: Sürmene-Çamburnu Nature Park, Scots pine forest, along the road, $10 \mathrm{~m}$ in NE Anatolia.

Materials and methods: Materials of the present study were collected during the field studies in the years 2019. They were processed according to standard herbarium techniques and stored at KATO herbarium in Karadeniz Technical University.

Main results: The genus Leptatherum Nees and its species L. boreale (Ohwi) C.-H. Chen, C.-S. Kuoh \& Veldk. (Poaceae) are reported as new genus and species for the vascular flora of Turkey. A new Turkish name of the species is also given.

Research highlights: This new vascular plant record is underlined that alien species from Japan and adjacent countries has been continued to introduce in NE Anatolia. Thus, chorological studies should be conducted for monitoring and eliminating the side effects of these invasive taxa in this region of Turkey.

Keywords: Alien Species, Anatolia, Leptatherum, Poaceae

\section{Leptatherum (Poaceae): Türkiye Florası İçin Yeni Bir Cins}

\section{Kaydı}

Öz

Çalışmanın amacı: Bu çalışma Türkiye'nin damarlı bitki çeşitliliğine katkı sağlamayı amaçlamaktadır.

Çalışma alanı: A8 Trabzon: Sürmene-Çamburnu Tabiat Parkı, Sarıçam ormanı, yol kenarları, $10 \mathrm{~m}$ Kuzeydoğu Anadolu.

Materyal ve yöntem: Bu çalışmanın materyalleri 2019 yılı içindeki arazi çalışmalarında toplanmıştır. Materyaller standart herbarium tekniklerine göre hazırlanarak, KTÜ Orman Fakültesi Herbaryumu (KATO)'na konulmuştur.

Temel sonuçlar: Leptatherum Nees cinsi ve L. boreale (Ohwi) C.-H. Chen, C.-S. Kuoh \& Veldk. türü (Poaceae), cins ve tür olarak Türkiye damarlı bitkileri listesi için ilk kez rapor edilmektedir. Türün yeni Türkçe adı da verilmektedir.

Araştırma vurguları: Bu yeni vasküler bitki kaydı, Japonya ve komşu ülkelerden gelen yabancı türlerin Kuzeydoğu Anadolu'da doğallaşmaya devam ettiğinin altını çizmektedir. Bu nedenle, bu istilacı taksonların Türkiye'nin bu bölgesindeki yan etkilerini izlemek ve ortadan kaldırmak için korolojik çalışmalar yapılmalıdır.

Anahtar kelimeler: Yabancı Tür, Anadolu, Leptatherum, Poaceae.

\section{Introduction}

The grass family (Poaceae / Gramineae) with approximately 11506 species and 768 genera (Perreta et al., 2009; Soreng et al., 2017 ) is both the fifth largest vascular plant family (Cabi et al., 2017; Perreta et al., 2009) and one of the 167 families of Turkish Flora (Güner et al., 2012). The genus Microstegium Ness. (Nat. Syst. Bot. ed. 2. 447 (1836)) belongs to the tribe
Andropogoneae Dum., with about 85 genera and ca. 1000 species (Wu et al., 2006), subtribe Saccharinae Griseb (Clayton, 1980). It was first distinguished as Pollinia Trin. (Trinius, 1832). The genus Leptatherum Nees were segregated from Microstegium depending mainly on ITS (Internal Transcribed Spacer) DNA (Chen et al., 2009). As well, this treatment has been accepted by many specialists of grass 
taxonomy in the world (Kellogg, 2015; Soreng et al., 2017).

Microstegium (the closely related genus of Leptatherum Ness) is reported with $M$. vimineum (Trin.) A. Camus, a problematic invader in NE Anatolia, by Scholz \& Byfield (2000) for the first time in Flora of Turkey. Microstegium is represented by 20 species in both India to Japan and SE Asia and a few species in tropical and subtropical Africa (Chen \& Phillips, 2006; Liu \& Peng, 2011; Chen et al., 2012; Chen et al., 2015). The genus Leptatherum used to be treated as a synonym of Microstegium. Leptatherum can be easily distinguished from Microstegium both with morphological traits (spikelet, pedicel, upper lemma and the number of stamens) (Chen et al., 2015) and molecular evidences (Chen et al., 2009). M. vimineum and M. nudum (Trin.) C.-H. Chen, C.-S. Kuoh, Veldk. (now Leptatherum nudum) are the types of Microstegium and Leptatherum respectively, and these species were not in one monophyletic clade but were separated far apart in the cladogram (Spangler et al., 1999). M. japonicum was added to the reinstated genus Leptatherum by Chen et al. (2009), and so were M. nudum and M. somae (Chen et al. 2009). Thus, Leptatherum is represented by three species from South Africa to China, Japan, S Korea, one of them in Malesia (Chen et al., 2015).

The ecological requirements for naturalization of alien plant taxa are extremely available in NE Anatolia. Especially, heavy rainfall and frequent mist throughout the year give chance to these plants easily colonizing in the region. $M$. vimineum was the only naturalized species of the close genus Microstegium in Turkey (Scholz \& Byfield 2000; Güner et al., 2000).

In the present study, genus Leptatherum and its species L. boreale (Ohwi) C.-H. Chen, C.-S. Kuoh, Veldk. (Poaceae) are reported as a new genus and species (with Turkish name) for the vascular flora of Turkey (A8-Trabzon in NE Anatolia). This genus and the species have never been reported from Turkey before.

\section{Material and Methods}

Studied materials of $L$. boreale were collected from Scots pine forest including Çamburnu Nature Park (A8-Trabzon, Sürmene) and coordinated by GPS (UTM 50 Datum). Materials of $M$. vimineum, which is the closest taxon to $L$. boreale in Turkish vascular flora, were collected from both Çamburnu and two different vicinities. All materials were stored at KATO Herbarium (in Karadeniz Technical University, Faculty of Forestry) in Trabzon.

After careful examination of the materials of two genera, Leptatherum and Microstegium (KATO: 24445!, 24446!, 24447 ! and 24448!), which were collected from A7 and A8 Trabzon province, and checking with proper literature (Scholz \& Byfield, 2000; Terzioğlu \& Anşin, 2001; Chen \& Phillips 2006; Chen \& Kuoh 2007; Chen et al., 2009; Güner et al., 2012; Uludağ et al., 2017), L. boreale was determined as a new alien record for the flora of Turkey.

\section{Results and Discussion}

Leptatherum boreale (Ohwi) C.-H. Chen, C.-S. Kuoh \& Veldk., Blumea 54: 179, (2009), (Figure 1).

Turkish Name: Asya Sakalotu.

Syn.: Microstegium boreale Ohwi, Microstegium nudum (Trin.) A.Camus var. boreale (Ohwi) Ohwi, Microstegium japonicum (Miq.) Koidz. var. boreale (Ohwi) Ohwi, Pollinia japonica Miq., Microstegium japonicum (Miq.) Koidz., Microstegium nudum (Trin.) A.Camus subsp. japonicum (Miq.) Tzvelev (Chen et al., 2009).

Slender annual, up to $80 \mathrm{~cm}$ long, culm node glabrous, culm rooting at lower nodes. Leaf sheaths glabrous with ciliate margin, blade ovate-lanceolate, $2-7 \times 0.6-1.2 \mathrm{~cm}$, apex acute, base rounded, ligule 0.2-0.5 mm., glabrous. Inflorescence with 3-7 racemes very slender, digitately arranged; rachis internodes filiform, glabrous, longer than spikelet; pedicels unequal, shorter ca. 1 $\mathrm{mm}$, longer ca. $2.5 \mathrm{~mm}$, glabrous; spikelet ca. 3-4 mm long, callus short hairy, lower glume equaling the spikelet, lower lemma oblong, membranous, muticous. Upper lemma veined, glabrous, awn apical. Upper palea absent or minute. Stamens 2. Fr. Oct.-Nov. Roadsides, $10-150 \mathrm{~m}$. 
Location: Trabzon, Sürmene, Çamburnu, in Scots pine forest including Çamburnu Nature Park, along the road, $10 \mathrm{~m}, 10.11 .2019$,
UTM: 0602590 - 4531287, KATO 24445! (Figure 1).

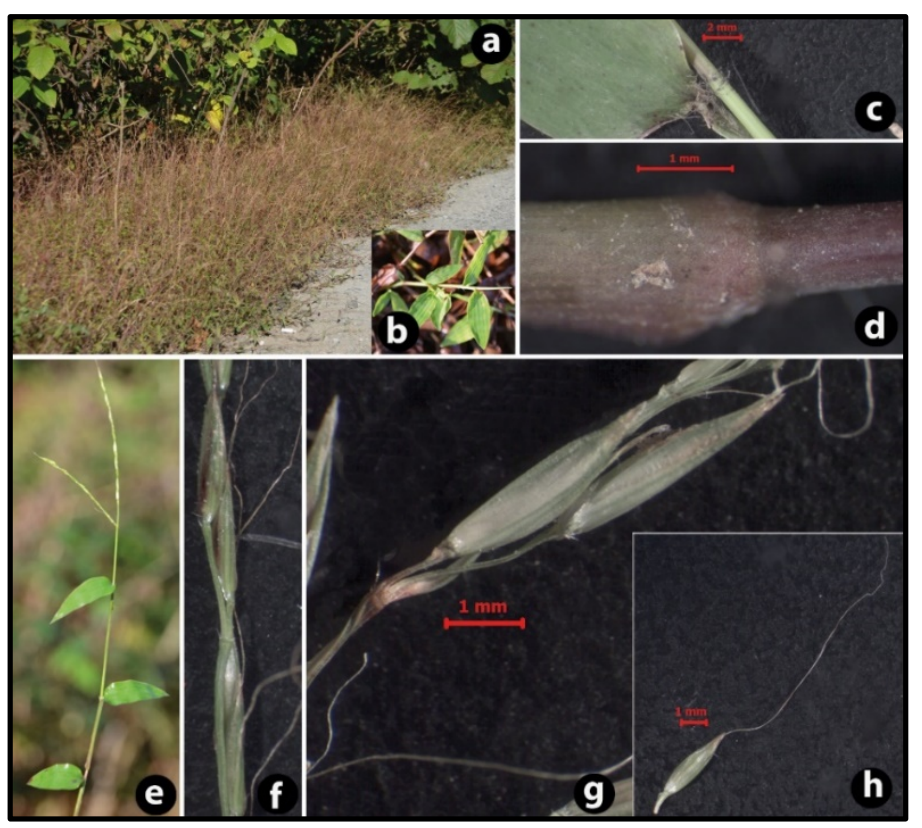

Figure 1. Leptatherum boreale: a-Habitat in Scots pine forest, along the road, b-Young culms, c-Leaf base, d- Glabrous node of culm, e- Upper portion of culm and inflorescence, f, gSpikelets of pair both unequally pedicelled, h- 1-awned spikelet

During the field studies, at first glance slender racemes and leaf bases of the studied individuals got our attention morphologically in the Scots pine forest. Two naturalized and closely related species belong to both Leptatherum and Microstegium have been observed in the same populations along the road. After the careful examination, we identified the specimens of the genera that they both belong to Leptatherum boreale and Microstegium vimineum (Figure 2). 


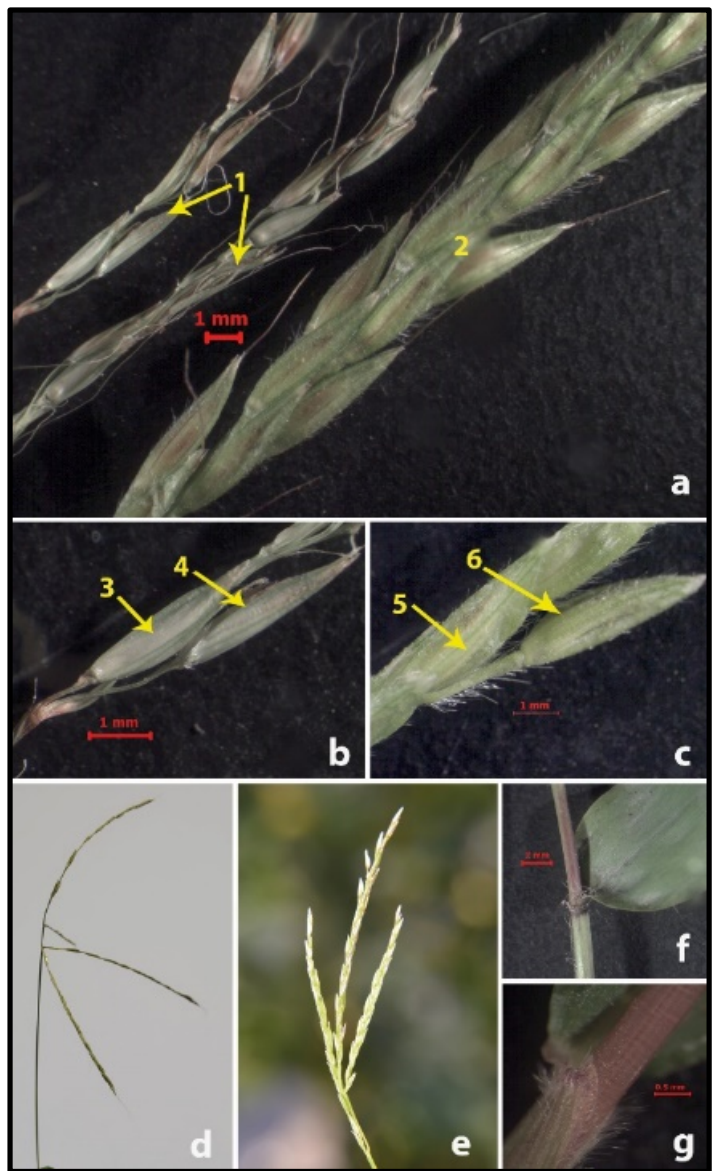

Figure 2. a- Raceme of Leptatherum boreale (1) and Microstegium vimineum (2), b- L. boreale -Spikelets of pair both unequally pedicelled $(3,4)$, c- $M$. vimineum- Portion of raceme showing sessile (5) and pedicellate (6) paired spikelets, d, e- Inflorescence of digitate racemes of $L$. boreale and $M$. vimineum respectively, $\mathrm{f}, \mathrm{g}-$ Leaf bases of $L$. boreale and $M$. vimineum respectively.

This new alien species from Scots pine forest are along with the native and naturalized (*) taxa listed below:

Alnus glutinosa (L.) Gaertn subsp. barbata (C.A.Mey.) Yalt., Arbutus unedo L, Arthraxon hispidus (Thunb.) Makino, Blechnum spicant (L.) Sm., Brachypodium sylvaticum (Huds.) P.Beauv., Calluna vulgaris (L.) Hull, Carex pendula Huds., Carpinus betulus L., Castanea sativa Mill., Centaurium erythraea Rafn., *Commelina communis L., *Conyza albida Willd. ex Spreng., Corylus avellana L., Drosera rotundifolia L., Epimedium pinnatum Fisch. ex DC. subsp. colchicum (Boiss.) N.Busch, Erica arborea L., Eupatorium cannabinum
L., Euphorbia amygdaloides L., Fagus orientalis Lipsky, Fragaria vesca L., Frangula dodonei Ard. subsp. dodonei, Hyalopoa pontica (Balansa) Tzvelev, *Hydrocotyle ramiflora Maxim., Hypericum calycinum L., Ilex colchica Pojark., Iris lazica Albov, Luzula forsteri (Sm.) DC., Lycopodium clavatum L., Lycopodium tristachyum Pursh, Melilotus albus Desr., Microstegium vimineum (Trin.) A.Camus, Omphalodes cappadocica (Willd.) DC., Oplismenus undulatifolius (Ard.) P.Beauv., Osmanthus decorus (Boiss. \& Balansa) Kasapligil, Osmunda regalis L., Oxalis corniculata L., Paspalum dilatatum Poir., * Phytolacca americana L., Picea orientalis (L.) Peterm., Pinus sylvestris L., Potentilla recta L., Prenanthes petiolata (K.Koch) Sennikov, Primula acaulis (L.) L., Primula megaseifolia Boiss. \& Balansa, Prunella vulgaris L., Pteridium aquilinum (L.) Kuhn, Pyracantha coccinea M.Roem., Quercus hartwissiana Steven, Quercus petraeae (Matt.) Liebl. subsp. iberica (Steven ex M.Bieb.) Krassiln., Rhododendron ponticum L., *Robinia pseudoacacia L., Rubus platyphyllus K.Koch, Salvia forskahlei L., Salvia glutinosa L., Sambucus ebulus L., Sanicula europae L., Satureja spicigera (K.Koch) Boiss., *Sicyos angulatus L., Sigesbeckia orientalis L., Smilax excelsa L., Sorbus torminalis (L.) Crantz, Vaccinium arctostaphylos L., Vicia cracca L. subsp. cracca, Viola sieheana W.Becker, Viscum album L. subsp. austriacum (Wiesb.) Vollman.

Well-established populations of $L$. boreale only exist in a very unique low-land Scots pine forest in Turkey. While we are not certain how this alien species got introduced to NE Anatolia. In recent times, it could have probably been carried to this forest by tourism activities. Approximately 5 hectares of this forest was established as a Nature Park, in 2011, used for tourism purposes. In accordance with this, many Asian alien species have been reported from Colchis sector of Euxine province in Turkey during the last decades (i.e. Scholz \& Byfield 2000; Terzioğlu \& Coşkunçelebi, 2017). Owing to its moderate temperature, this alien taxon has been able to established dense populations in the studied area. Because of its reported 
naturalization in Azerbaijan, Armenia and Georgia (Czerepanov, 2007; Euromed 2020, Davitadze et al., 2014), its distribution in this part of Turkey is not surprising. According to Chen \& Philips (2006) and Chen et al.,
(2015), a more detailed comparison of morphological characters of the new record, L. boreale, and other species of the genus are summarized in Table 1.

Table 1. Morphological comparison of Leptatherum species

\begin{tabular}{|c|c|c|c|}
\hline Characters & L. boreale & L. somae & L. nudum \\
\hline Culms long & Up to $80 \mathrm{~cm}$ & Up to $40 \mathrm{~cm}$ & Up to $100 \mathrm{~cm}$ \\
\hline $\begin{array}{l}\text { Pedicell of } \\
\text { spikelet }\end{array}$ & $\begin{array}{l}\text { Lower and upper } \\
\text { pedicellate }\end{array}$ & $\begin{array}{l}\text { Lower and upper } \\
\text { pedicellate }\end{array}$ & $\begin{array}{l}\text { Only upper } \\
\text { pedicellate }\end{array}$ \\
\hline Nodes & Glabrous & Glabrous or pubescent & $\begin{array}{l}\text { Glabrous or } \\
\text { pubescent }\end{array}$ \\
\hline Ligule & Glabrous & Glabrous & Ciliolate \\
\hline Blade & $\begin{array}{l}\text { Ovate to lanceolate, } 2-7 \\
\mathrm{~cm}\end{array}$ & $\begin{array}{l}\text { Ovate to lanceolate, } 3-4 \\
\mathrm{~cm}\end{array}$ & Lanceolate, $1-8 \mathrm{~cm}$ \\
\hline Racemes & $3-7$ & $2-7$ & $2-10$ \\
\hline Lower lemma & Oblong & Lanceolata & Lanceolata \\
\hline $\begin{array}{l}\text { Lower lemma } \\
\text { apex }\end{array}$ & Muticous & Awned & Muticous \\
\hline $\begin{array}{l}\text { Upper glume } \\
\text { apex }\end{array}$ & Muticous & Awned & Muticous \\
\hline
\end{tabular}

This newly recorded species is found out to scatter in Scots pine forest of Çamburnu district, but its possible dispersion range should be monitored in NE Anatolia.

Examined Specimens: Microstegium vimineum: A8-Trabzon: Of, Kumludere, 180 m., 25.10.2013, KATO: 8786!, (10.11.2019) ibid!, 24447!, Sürmene, Çamburnu, 03.11.2019, KATO:24446!, A7-Trabzon: Yomra, Kavala, 14. 11.2019, KATO: 24448!

\section{References}

Cabi, E., Soreng, R.J., Gillespie, L.J \& Boudko, E. (2017). Alopecurus goekyigitiana (Poaceae, subtribe Alopecurinae sensu stricto), a new species from Turkey based on morphological and molecular investigation. Turkish Journal of Botany, 41, 189-199.

Chen, S. \& Phillips, S.M. (2006). Microstegium Nees. In: Wu Z-Y, Raven PR (eds), Flora of China, 22, 593-598. Science Press, Beijing, Missouri Botanical Garden Press, St. Louis.

Chen, C.H. \& Kuoh, C.S. (2007). Microstegium japonicum (Miq.) Koidz. as a newly recorded grass to Taiwan. Endemic Species Research, 8, 77-80.

Chen, C.H., Veldkamp, J.F., Kuoh, C.S., Tsai, C.C. \& Chiang, Y.C. (2009). Segregation of Leptatherum from Microstegium (Andropogoneae, Poaceae) confirmed by
Internal Transcribed Spacer DNA sequences. Blumea, 54, 175-180.

Chen, C.H., Veldkamp, J.F. \& Kuoh, C.S. (2011). Microstegium glabratum (Brongn.) A. Camus (Poaceae, Andropogoneae), a new record for Japan, China, and Taiwan, based on morphological and molecular evidence. Taiwania, 56, 111-117.

Chen, C.H., Veldkamp, V.F. \& Kuoh, C.S. (2012). Taxonomic revision of Microstegium s.str. (Andropogoneae, Poaceae). Blumea, 57, 160-189.

Chen, C.H., Lin, C.Y. \& Kuoh, C.S. (2015). Grass Flora of Taiwan, 3, Endemic Species Research Institute, Chichi, Taiwan.

Clayton, W.D. (1980). Notes on the tribe Andropogoneae (Gramineae). Kew Bulletin, 35, 813-818.

Czerepanov, S.K. (2007). Vascular Plants of Russia and Adjacent States (the former USSR). Cambridge University Press, Newyork.

Davitadze, M., Mickeladze, I., Bolkvadze, G., Metreveli, M. \& Chagalidze R. (2014). Life Forms of Invasive Herbaceous Plants of the South Colchis. Modern Phytomorphology, 6, 189-193.

Euromed. (2020, Jan.). luomus.fi/ euro med map.php?taxon $=534150 \&$ size $=$ medium

Güner, A., Aslan, S., Ekim, T., Vural, M. \& Babaç, M.T. (Edits.) (2012). Türkiye Bitkileri Listesi (Damarlı Bitkiler). Nezahat Gökyiğit 
Botanik Bahçesi ve Flora Araştırmaları Derneği, Yayın no:1, İstanbul.

Güner, A., Özhatay, N., Ekim, T. \& Başer K.H.C. (Eds.). (2000). Flora of Turkey and the East Aegean Islands, supplement 2, University Press, Edinburgh.

Kellogg, E.A. (2015). Flowering plants, monocots, Poaceae. In: Kubitski K ed. The families and genera of vascular plants. Cham: Springer International. 13, 1-416.

Liu, Y.C. \& Peng, H. (2011). Microstegium butuoense (Poaceae), a new Species from Sichuan, China. Annales Botanici Fennici, 48, 182-184.

Perreta, M.G., Ramos, J.C. \& Vegetti, A.C. (2009). Development and structure of the grass inflorescence. The Botanical Review, 75, 377-396.

Scholz, H. \& Byfield, A.J. (2000). Three Grasses New to Turkey. Turkish Journal of Botany, 24, 263-267.

Soreng, R.J., Peterson, P.M., Romaschenko, K., Davidse, G., Teisher, J.K., Clark, L.G., Barberá, P., Gillespie, L.J. \& Zuloaga, F.O. (2017). A worldwide phylogenetic classification of the Poaceae (Gramineae) II: An update and a comparison of two 2015 classifications. Journal of Systematics and Evolution, 55(4), 259-290.
Spangler, R., Zaitchik, B., Russo, E. \& Kellogg, E. (1999). Andropogoneae evolution and generic limits in Sorghum (Poaceae) using ndhF sequences. Systematic Botany 24, 267281.

Terzioğlu, S. \& Anşin, R. (2001). A Chorological Study on Taxa Naturalized in The Eastern Black Sea Region. Turkish Journal of Agriculture and Forestry, 25, 305-309.

Terzioğlu, S. \& Coşkunçelebi, K. (2017). Rhus chinensis var. chinensis (Anacardiaceae): a new alien record for the flora of Turkey. Phytologia Balcanica, 23(2), 167-170.

Trinius, CB. (1832). Andropogoneorum genera speciesque. Mémoires de l'Academie Imperiale des Sciences de Saint-Petersbourg. Sixieme Serie. Sciences Mathematiques, Physiques et Naturelles. Seconde Partie: Sciences Naturelles, 2, 304, 307.

Uludağ, A., Aksoy, N., Yazlık, A., Arslan, Z.F., Yazmış, E., Üremiş, İ., Cossu, T.A., Groom, Q., Pergl, J., Pyšek, P. \& Brundu, G. (2017). Alien flora of Turkey: checklist, taxonomic composition and ecological attributes. NeoBiota, 35, 61-85.

Wu, Z.Y., Raven, P.H. \& Hong D.Y. (Eds.). (2006). Flora of China, 22. Poaceae. Science press, Beijing and Missouri Botanical Garden Press, St. Louis. 